\title{
BURIED ALIVE: THE REBOOT OF THE EQUAL RIGHTS AMENDMENT Gerard N. Magliocca*
}

Section 1. Equality of rights under the law shall not be denied or abridged by the United States or by any State on account of sex.

Section 2. The Congress shall have the power to enforce, by appropriate legislation, the provisions of this article.

Section 3. This amendment shall take effect two years after the date of ratification. ${ }^{1}$

In 2017, Nevada ratified the proposed Equal Rights Amendment ("ERA") to the

Constitution. ${ }^{2}$ This vote occurred thirty-five years after the expiration of the deadline set by

Congress for three-fourths of the state legislatures to ratify the ERA. ${ }^{3}$ Nevertheless, the Nevada

Legislature maintained that its action was not symbolic. ${ }^{4}$ The state argued that Congress could

waive the expired deadline and declare the ERA the Twenty-Eighth Amendment whenever three-

quarters of the states (thirty-eight) ratify. ${ }^{5}$ Drawing on Nevada's action and on the momentum

for women's rights created by the \#MeToo movement, Illinois ratified the ERA in $2018 .^{6}$

This Article argues that Congress can recognize the ERA as part of the Constitution

despite the expiration of the ratification deadline in 1982. But Congress should not do so until

\footnotetext{
* Samuel R. Rosen Professor, Indiana University Robert H. McKinney School of Law. I thank Dan Cole, Brian Kalt, Sandy Levinson, Richard Primus, and Amanda Tyler for offering comments on prior drafts of this paper.

${ }^{1}$ H.R.J. Res. 208, 92d Cong., 2d Sess., 86 Stat. 1523 (1972).

${ }^{2}$ S.J. Res. 2, 79th Gen. Assemb., Reg. Sess. (Nev. 2017).

${ }^{3}$ See H.R.J. Res. 638, 95th Cong., 92 Stat. 3799 (1978) (giving the ERA ratification deadline as June 30, 1982). The initial ratification deadline for the ERA expired in March 1979. See DAVID E. KYVIG, EXPLICIT AND AUTHENTIC ACTS: AMENDING THE U.S. CONSTITUTION, 1776-1995, at 413-15 (1996). Part II explores whether Congress has the authority to impose a ratification deadline via a joint resolution. See infra text accompanying notes 50-56.

${ }^{4}$ States sometimes (for ceremonial purposes) ratify amendments that are already part of the Constitution. See Gerard N. Magliocca, The Heart of the Constitution: How The Bill of Rights Became the Bill of RIGHTS 100 (2018) (noting the ratification of the first ten amendments in 1939 by three states that did not do so in the 18 th century).

5 See Nev. S.J. Res. 2. Nevada's ratification rationale was first advanced in a law review article. See Allison L. Held, Sheryl L. Herndon \& Danielle M. Stager, The Equal Rights Amendment: Why the ERA Remains Legally Viable and Properly Before the States, 3 WM. \& MARY J. WOMEN \& L. 113, 114-15 (1997).

${ }^{6}$ See S.J. Res. Const. Amend. 4, 100th Gen. Assemb., Reg. Sess. (Ill. 2018); Matthew Haag, The Equal Rights Amendment Was Just Ratified by Illinois. What Does That Mean?, N.Y. TIMES (May 31, 2018), https://www.nytimes.com/2018/05/31/us/equal-rights-amendment-illinois.html.
} 
there is no doubt that thirty-eight states have ratified the ERA. There is room for doubt on that score because five states rescinded their ratification votes in the 1970 s. ${ }^{7}$ Congress is probably free to disregard these rescissions on the ground that a state may not repeal its ratification of a proposed constitutional amendment. ${ }^{8}$ If these rescissions are disregarded, then the ERA stands just one state short of the thirty-eight needed for ratification. Ignoring these state rescissions in addition to waiving the ratification deadline, however, would raise substantial concerns about the ERA's legitimacy and might lead a future Congress to contest that recognition. Accordingly, the wise course is for Congress to refrain from acting on the ERA until thirty-eight states can be counted as yes votes without the rescinding states. ${ }^{9}$ If Congress decides to include the rescinding states as part of the ratification total, then at least two-thirds of the Senate and the House of Representatives should be required to support that choice - in accord with the precedent set by Fourteenth Amendment — to quiet doubts about the validity of the ERA's ratification. ${ }^{10}$ Even if either of these strict ratification standards is met, Congress must still weigh whether the expired ratification deadline should be waived. The ratification of the TwentySeventh Amendment established that over two centuries can pass between an amendment's

\footnotetext{
${ }^{7}$ See KYvig, supra note 3, at 408-09, 415 (listing the rescinding states as Idaho, Kentucky, Nebraska, Tennessee, and South Dakota). Some question if Kentucky's rescission is valid because the state legislature's resolution was vetoed by the Acting Governor. See Held, Herndon \& Stager, supra note 5, at 134 n.124; Around the Nation: Acting Governor Vetoes Kentucky Rights Reversal, N.Y. TIMES, Mar. 21, 1978, at 20. This claim lacks merit. First, Article $\mathrm{V}$ refers to ratification by only state legislatures or state conventions and gives no role to state executives. See U.S. CONST. art. V. Second, I can find no practice in Kentucky or in any other state that gives the Governor a formal role in the Article V process. Third, the Kentucky Constitution states that the Governor plays no role in approving a proposed state constitutional amendment. See KY. CONST. § 256. Since the Governor is excluded from the amending process in Kentucky, there is no basis for thinking that the Governor can participate in the federal amending process. ${ }^{8}$ See Coleman v. Miller, 307 U.S. 433, 450 (1939). See generally Peter Michael Jung, Note, Validity of a State's Rescission of Its Ratification of a Federal Constitutional Amendment, 2 HARV. J.L. \& PUB. POL'Y 233, 234 (1979) (providing an overview of this issue).

${ }^{9}$ Nothing prevents any of these five states from rescinding their rescission, but this Article proceeds on the assumption that none of them will.

${ }^{10}$ See infra text accompanying notes 91-103, 119-22.
} 
proposal and its ratification. ${ }^{11}$ There are, however, distinctions between the Twenty-Seventh Amendment and the ERA that counsel against waiving the deadline, such as the greater potential breadth of the ERA and the unfairness involved in changing the rules after everyone thought the game was over. ${ }^{12}$ On the other hand, there are some arguments in favor of waiver, such as the potential popularity of adding an expression of sex equality in the Constitution and the belief that the ERA is necessary given the growing importance of originalism in our constitutional culture. ${ }^{13}$ This Article takes no position on whether Congress should waive the ERA ratification deadline, as there is no way to predict the social, legal, and political conditions that will prevail when and if Congress faces that choice.

Part I provides some background on the ERA and on its recent revival in state legislatures. Part II defends the authority of Congress to impose and change a ratification deadline that is not included in the text of a proposed constitutional amendment. Part III argues that Congress should not exercise its discretion to dismiss the votes by five states to rescind their ratifications of the ERA, in part because the conclusion that a state vote for ratification is final cannot be sensibly reconciled with the conclusion that a national ratification deadline is not final. Part IV concludes by assessing some of the considerations that should guide Congress's decision on whether to waive the ERA deadline and declare the text part of the Constitution.

\footnotetext{
${ }^{11}$ See U.S. ConsT. amend. XXVII; Richard Albert, Temporal Limitations in Constitutional Amendment, 21 REV. Const. STUd. 37, 47 (2016); Saikrishna Bangalore Prakash, Of Synchronicity and Supreme Law 5 (Univ. of Va. Sch. of Law Pub. Law \& Legal Theory Research Paper Series, Paper No. 2018-04, 2018), https://papers.ssrn.com/sol3/papers.cfm?abstract_id=3109720. See generally Michael Stokes Paulsen, A General Theory of Article V: The Constitutional Lessons of the Twenty-Seventh Amendment, 103 YALE L.J. 677, 681 (1993) (examining the broader implications of the Twenty-Seventh Amendment's ratification).

${ }^{12}$ See, e.g., Craig v. Boren, 429 U.S. 190, 207-10 (1976) (establishing intermediate scrutiny as the standard of review for sex classifications that are challenged pursuant to the Equal Protection Clause); see Brannon P. Denning \& John R. Vile, Necromancing the Equal Rights Amendment, 17 CONST. COMMENT. 593, 596-98 (2000) (noting other differences between the Twenty-Seventh Amendment and the ERA).

${ }^{13}$ See Coleman, 307 U.S. at 454 (stating that whether an Article V amendment is ratified "can be decided by the Congress with the full knowledge and appreciation ascribed to the national legislature of the political, social and economic conditions which have prevailed during the period since the submission of the amendment"); infra Part IV.
} 


\section{PART I-A BRIEF HISTORY OF THE ERA (THUS FAR)}

Until 2017, the conventional wisdom was that the ERA was dead. ${ }^{14}$ This Part explains why that conclusion was reached and how that opinion began unraveling after the ratification of the Twenty-Seventh Amendment in 1992. A key insight came from a 1997 law review article, which contended that the Twenty-Seventh Amendment meant that Article V proposals without a ratification deadline in their text can always be deemed ratified by Congress if three-quarters of the states concur. ${ }^{15}$ The ERA's ratification time limit is not in the amendment's text. Instead, the deadline (amended by a subsequent Congress) was in a joint resolution that was sent to the states along with the ERA. ${ }^{16}$ Twenty years after the 1997 article was published, Nevada implicitly adopted the paper theory by ratifying the ERA and by stating that Congress can make that text part of the Constitution. ${ }^{17}$ When Illinois followed in 2018, the ERA's fate became a live issue. ${ }^{18}$

\section{A. The Creation and Extension of the ERA Ratification Deadline}

In 1972, more than two-thirds of each house of Congress voted to send the ERA to the States. ${ }^{19}$ Consistent with the practice followed by the previous four constitutional amendments, Congress placed a seven-year ratification deadline in the text of the joint resolution adopting the ERA. ${ }^{20}$ The "Joint Resolution Proposing an amendment to the Constitution of the United States

\footnotetext{
${ }^{14}$ See KYvig, supra note 3, at 468 (describing the expiration of the ratification deadline in 1982 as "a fatal stumbling block to the ERA"); Larry Kramer, Generating Constitutional Meaning, 94 CALIF. L. REV. 1439, 1444 (2006) (referring to "the failed Equal Rights Amendment"); Ira C. Lupu, When Cultures Collide, 103 HARV. L. REV. 951, 961 (1990) (describing "[t]he struggle, ultimately unsuccessful, over ratification of the Equal Rights Amendment"). By "dead," I mean that that the ERA could not be formally ratified. The equality that the ERA sought to further fared far better through the Equal Protection Clause. See AKHIL REED AMAR, AmERICA's Unwritten Constitution: The PReCEdents AND PRINCIPLES We Live By 295-96 (2012).

${ }^{15}$ See Held, Herndon \& Stager, supra note 5, at 114-15.

${ }^{16}$ H.R.J. Res. 208, 92d Cong., 2d Sess., 86 Stat. 1523 (1972).

${ }^{17}$ See S.J. Res. 2, 79th Gen. Assemb., Reg. Sess. (Nev. 2017). There is no doubt from the text of the recent Nevada and Illinois ratification resolutions that each state legislature believed that it was ratifying the ERA in the hope that Congress would waive the deadline. See id.; S.J. Res. Const. Amend. 4, 100th Gen. Assemb., Reg. Sess. (Ill. 2018).

18 S.J. Res. Const. Amend. 4, 100th Gen. Assemb., Reg. Sess. (Ill. 2018).

${ }^{19}$ H.R.J. Res. 208; see also Frontiero v. Richardson, 411 U.S. 677, 687 (1973) (plurality opinion).

${ }^{20}$ See KYvig, supra note 3, at 414; Held, Herndon \& Stager, supra note 5, at 124.
} 
relative to equal rights for men and women" provided that the ERA would be valid "when

ratified by the legislatures of three-fourths of the several States within seven years from the date

of its submission by the Congress." ${ }^{21}$ Following this preface, the joint resolution listed the text of the proposed ERA, which contained no ratification deadline. ${ }^{22}$ This structure contrasted with four constitutional amendments that included a seven-year ratification deadline in their actual text. ${ }^{23}$

In 1978, Congress amended the ERA joint resolution and extended the ratification deadline to ten years. ${ }^{24}$ This decision generated vigorous academic debate on whether Congress could extend the ratification time limit of a proposed Article $\mathrm{V}$ amendment when that limit was not in the amendment's text, including a law review article by Professor Ruth Bader Ginsburg. ${ }^{25}$ No states ratified the ERA in the extension period, but South Dakota did rescind its ratification as of the date when the original deadline expired due to the belief that the extension of time was wrong. ${ }^{26}$ When the new deadline expired in 1982, Congress chose to reintroduce the amendment

\footnotetext{
${ }^{21}$ H.R.J. Res. 208.

${ }^{22}$ See supra text accompanying note 1.

${ }^{23}$ U.S. CONST. amend. XXII, $\S 2$ ("This article shall be inoperative unless it shall have been ratified as an amendment to the Constitution by the legislatures of three-fourths of the several States within seven years from the date of its submission to the States by the Congress."); id. amend. XXI, $\S 3$ ("This article shall be inoperative unless it shall have been ratified as an amendment to the Constitution by conventions in the several States, as provided in the Constitution, within seven years from the date of the submission hereof to the States by the Congress."); id. amend. XX, $\S 6$ ("This article shall be inoperative unless it shall have been ratified as an amendment to the Constitution by the legislatures of three-fourths of the several States within seven years from the date of its submission."); $i d$. amend. XVIII, § 3 ("This article shall be inoperative unless it shall have been ratified as an amendment to the Constitution by the legislatures of the several States, as provided in the Constitution, within seven years from the date of the submission hereof to the States by the Congress."); see infra text accompanying notes 5960.

${ }^{24}$ See H.R.J. Res. 638, 95th Cong., 92 Stat. 3799 (1978) (“That notwithstanding any provision of House Joint Resolution 208 of the Ninety-second Congress, second session, to the contrary, the article of amendment proposed to the States in such joint resolution shall be valid to all intents and purposes as part of the Constitution when ratified by the legislatures of three-fourths of the several States not later than June 30, 1982."). For an excellent discussion of the ERA ratification debate in the states, see Reva B. Siegel, Constitutional Culture, Social Movement Conflict and Constitutional Change: The Case of the de Facto ERA, 94 CALIF. L. REV. 1323 (2006).

${ }^{25}$ Compare Ruth Bader Ginsburg, Ratification of the Equal Rights Amendment: A Question of Time, 57 TEX. L. REV. 919, 929-30 (1979) (arguing for the validity of the extension), with Grover Rees III, Throwing Away the Key: The Unconstitutionality of the Equal Rights Amendment Extension, 58 TEX. L. REV. 875, 876 (1980) (rejecting that contention).

${ }^{26}$ See S.J. Res. 2, 54th Leg. Assemb., Reg. Sess. (S.D. 1979); infra text accompanying notes 106-09. A district court held the extension invalid, but that decision was vacated as moot after the ratification deadline expired in a
} 
and seek a fresh mandate from two-thirds of the House of Representatives and of the Senate (which never came from either House) instead of extending the ERA ratification timeframe for a second time. ${ }^{27}$ R.I.P. ERA, or so it seemed.

\section{B. The Twenty-Seventh Amendment and a Flash of Insight}

In 1992, three-fourths of the states ratified a constitutional amendment proposed by James Madison during the first Congress. ${ }^{28}$ This proposal barred Congress from altering the salaries of its members during a given Congress. ${ }^{29}$ Contrary to dicta in a 1921 Supreme Court opinion that declared "quite untenable" the argument that a constitutional text could be ratified more than a century after being submitted to the states, ${ }^{30}$ Congress passed a joint resolution recognizing the Twenty-Seventh Amendment as part of the Constitution. ${ }^{31}$ Congress relied instead on a 1939 Supreme Court opinion, Coleman v. Miller, which held that the issue of whether too much time had elapsed for the states to ratify a proposed Article V amendment rested with Congress and could not be examined by the courts. ${ }^{32}$

While this validation occurred without much discussion, Senator William Roth of Delaware realized that Congress's decision opened the door for a ratification of Article V amendments with expired deadlines. Roth told the Senate that the Twenty-Seventh Amendment

\footnotetext{
brief order by the Supreme Court. See Idaho v. Freeman, 529 F. Supp. 1107, 1153 (D. Idaho 1981), vacated as moot, Nat'l Org. of Women, Inc. v. Idaho, 459 U.S. 809 (1982).

${ }^{27}$ See Serena Mayeri, A New E.R.A. or a New Era? Amendment Advocacy and the Reconstruction of Feminism, 103 Nw. U. L. REV. 1223, 1224 (2009). In this case, Congress was exercising its discretion over the Article V process. The decision not to extend the ratification deadline in 1982 does not mean that Congress could not have done so. ${ }^{28}$ See Michael J. Klarman, The Framers' Coup: The Making of the United States Constitution 579, 59091 n.* (2016).

${ }^{29}$ See U.S. CONST. amend. XXVII ("No law, varying the compensation for the services of the Senators and Representatives, shall take effect, until an election of Representatives shall have intervened.").

${ }^{30}$ Dillon v. Gloss, 256 U.S. 368, 375 (1921).

${ }^{31}$ See 138 CONG. REC. 11869 (1992) (Senate vote); id. at 12051-52 (House vote). Some scholars are critical of this decision. See, e.g., Prakash, supra note 11, at 8 . To the extent that a future Congress takes this criticism to heart, the response may be to choose not to waive the ERA's ratification deadline and compound the error made in 1992.

32307 U.S. 433, 456 (1939); see 138 CONG. REC. 11860 (1992) (statement of Sen. Grassley); id. at 11653-54 (statement of Sen. Byrd).
} 
created "a very important precedent. Senate adoption of these resolutions means that a proposed constitutional amendment, once believed ineffective through the passage of time, can be revived and ratified." ${ }^{33}$ The Senator added:

If a proposed amendment need not be ratified by the requisite number of States contemporaneously, a fact we now declare by these resolutions, then why cannot the States ratify other long-forgotten amendments? Then why cannot the States ratify even the expired amendments - those which failed ratification before a congressionally imposed deadline-in the hope that Congress would later extend the deadline? ? $^{34}$

Why indeed?

The link between Senator Roth's observations on the ratification of the Twenty-Seventh Amendment and the ERA was picked up five years later in a law review article (subtitled Why the ERA Remains Legally Viable and Properly Before the States) co-authored by three law students. ${ }^{35}$ While the paper's substantive arguments are assessed in Part II, a key point was that the Twenty-Seventh Amendment established that there was no unwritten constitutional norm barring the ratification of an amendment because too much time had passed between its proposal by Congress and the affirmative votes of three-fourths of the states. ${ }^{36}$ Without such a norm, the article argued, nothing prevented Congress from changing the ERA ratification deadline again so that the amendment could be ratified. ${ }^{37}$ The article provided the underpinning for the "ThreeState Strategy," which rested on the premise that the ERA needed three more state ratifications to

\footnotetext{
33138 CONG. REC. 11871 (1992) (statement of Sen. Roth).

${ }^{34} \mathrm{Id}$.

35 See Held, Herndon \& Stager, supra note 5, at 113 (mentioning the affiliation of the three authors).

${ }^{36}$ See id. at 121-23. See generally Keith E. Whittington, The Status of Unwritten Constitutional Conventions in the United States, 2013 U. ILL. L. REV. 1847, 1847 (2013) (discussing the important role of these constitutional customs).

${ }^{37}$ See Held, Herndon \& Stager, supra note 5, at 135.
} 
cross the three-fourths threshold mandated by Article V (a premise challenged in Part III) and return the issue to Congress. ${ }^{38}$

\section{The Nevada and Illinois Ratifications of the ERA}

The "Three-State Strategy" was purely academic until Nevada voted to ratify the ERA in 2017. ${ }^{39}$ In its joint resolution explaining the decision, the State endorsed the logic of Senator Roth and the 1997 law review article. After restating the text and history of the ERA, the resolution stated that "[t]he Congress of the United States adopted the 27th Amendment to the Constitution of the United States, which was proposed in 1789 by our First Congress but not ratified by three-fourths of the States until May 7, 1992, and, on May 18, 1992, certified as the 27th Amendment." ${ }^{40}$ Next, Nevada opined that "[t]he restricting time limit for ratification of the Equal Rights Amendment is in the resolving clause and is not part of the amendment which was proposed by Congress and which has already been ratified by 35 states." 41 Then, "[h]aving passed a time extension for the Equal Rights Amendment on October 20, 1978, Congress demonstrated that a time limit in a resolving clause may be disregarded if it is not part of the proposed amendment." ${ }^{42}$ A statement of the Court's holding in Coleman followed, ${ }^{43}$ which led to

\footnotetext{
${ }^{38}$ See Held, Herndon \& Stager, supra note 5, at 117-23; Two Modes of Ratification, EQUAL RIGHTS AMENDMENT, ALICE PAUL INST., https://www.equalrightsamendment.org/ratification-1/ (last visited June 20, 2018) (providing background on the three-state strategy).

${ }^{39}$ In 2013, the New Mexico Senate passed a resolution urging that state's congressional delegation to vote in favor of waiving the ERA's deadline. See S. Mem'1 7, 51st Leg., 1st Sess. (N.M. 2013). This resolution provided a brief summary of the "Three-State Strategy." See id. ("[T]he deadline for ratification is not in the binding text of the document itself and, in fact, was later extended by another congress for an additional three years, thus establishing the precedent that congress has the power to do so.").

${ }^{40}$ S.J. Res. 2, 79th Gen. Assemb., Reg. Sess. (Nev. 2017).

${ }^{41} I d$. The claim that 35 states had ratified the ERA prior to Nevada rests on the assumption that the five rescinding states should still be counted as ratifying states. See KYVIG, supra note 3, at 408-09 (pointing out that thirty states ratified the ERA in the first year after its proposal, but only five did thereafter, while four others rescinded prior to the extension of the deadline); $i d$. at 415 (noting the rescission by South Dakota after the extension was passed by Congress).

${ }^{42}$ Nev. S.J. Res. 2.

${ }^{43}$ Id. ("The United States Supreme Court in Coleman v. Miller, 307 U.S. 433 (1939), recognized that Congress is in a unique position to judge the tenor of the nation, to be aware of the political, social and economic factors affecting the nation and to be aware of the importance to the nation of the proposed amendment ....").
} 
the conclusion that "it is for Congress, under the principles of Coleman v. Miller, to determine the validity of the state ratifications occurring after a time limit in the resolving clause, but not in the amendment itself." ${ }^{44}$ Last, the joint resolution stated that "the present political, social and economic conditions demonstrate that constitutional equality for women and men continues to be a timely issue in the United States." ${ }^{45}$

In May 2018, Illinois ratified the ERA. ${ }^{46}$ The Illinois Joint Resolution closely tracked Nevada's reasoning with two exceptions. First, the resolution stated: "The founders of our nation, James Madison included, did not favor further restrictions [in other words, time limits on ratification] to Article $\mathrm{V}$ of the Constitution of the United States, the amending procedure; the United States Constitution is harder to amend than any other constitution in history ...."47 While the claim about "any other constitution in history" is highly questionable, the fact that the Constitution is hard to amend is a fact that Congress may consider when addressing the ERA's ratification. ${ }^{48}$ Next, the resolution said: "[E]quality for women and men continues to be timely in the United States and worldwide, and a number of other nations have achieved constitutional equality for their women and men ...."49 The point about the inclusion of sex equality in other national constitutions could also influence Congress's judgment on ratification down the road if consistency with other liberal democracies is viewed as an important objective. ${ }^{50}$

\footnotetext{
${ }^{44} I d$.

${ }^{45} I d$.

${ }^{46}$ S.J. Res. Const. Amend. 4, 100th Gen. Assemb., Reg. Sess. (Ill. 2018).

${ }^{47} I d$.

48 See SANFord LeVinson, Our Undemocratic Constitution: Where the Constitution Goes Wrong (and How We tHE PEOPLE CAN CORRECT IT) 21 (2006) (noting the relative difficulty of amending the Constitution). This fact could cut either way. The difficulty of amendment could be invoked as a reason to waive the deadline on the ground that too often the popular will is thwarted by Article V. Or the idea could be that the Constitution should be difficult to amend and no leeway should be given to Congress to undo the decision of a prior Congress on the ERA. ${ }^{49}$ Ill. S.J. Res. Const. Amend. 4.

${ }^{50}$ See, e.g., Canadian Charter of Rights and Freedoms, Part I of the Constitution Act, 1982, being Schedule B to the Canada Act, 1982, c 15 (U.K.); GRUNDGESETZ [GG] [BASIC LAW] art. III, translation at https://www.gesetze-iminternet.de/englisch_gg/index.html\#gl_p0033.
} 
In sum, there is an active social movement seeking the ERA's ratification. But the lofty rhetoric from Nevada and Illinois will count for little if Congress lacks the authority to revise the ERA's expired ratification deadline. Let us therefore turn to that pivotal question.

\section{PART II-THE ARTICLE V AUTHORITY OF CONGRESS}

This Part assesses whether Congress can declare the ERA part of the Constitution if three-fourths of the states ratify the proposal. The answer is yes. My conclusion rests on an analysis of the text, history, and case law on the Article V process, which all imply that a ratification deadline not in the text of a proposed constitutional amendment can be altered by Congress at any time. In the ERA's case, Congress has already changed the deadline once by a majority vote in each chamber, which suggests that there is no barrier to doing so again through the proper form of a joint resolution.

\section{A. The Implied Power of Congress to Set a Deadline}

The first question that must be addressed is whether the ERA ratification deadline is constitutional. While there is clear authority from the Supreme Court that Congress may include such a deadline in the text of an Article V amendment, there is no such authority about the power of Congress to do this via a joint resolution. ${ }^{51}$ Furthermore, no power to impose a ratification deadline is stated in the Constitution. The power must be implied from Article V or from the Necessary and Proper Clause, as interpreted in $M$ 'Culloch v. Maryland.${ }^{52}$ In effect, the argument would be that setting a time limit is a reasonable means by which Congress was implementing the enumerated end of proposing amendments to the states. ${ }^{53}$

\footnotetext{
${ }^{51}$ See Dillon v. Gloss, 256 U.S. 368, 375-76 (1921); Held, Herndon \& Stager, supra note 5, at 127. Under the Court's subsequent analysis in Coleman, there are serious doubts about whether the constitutionality of a joint resolution time limit is justiciable. See infra text accompanying notes 76-80.

5217 U.S. (4 Wheat.) 316 (1819); see U.S. ConST. art. I, § 8, cl. 18. There is nothing about the original public meaning of Article $\mathrm{V}$ that sheds light on this question.

${ }^{53}$ See M'Culloch, 17 U.S. (4 Wheat.) at 408-10. Another way of putting this is that a time limit is just a procedural requirement rather than a substantive act.
} 
One point in favor of Congress's implied authority for using a joint resolution to set a ratification deadline is that this was done for Article V amendments other than the ERA. ${ }^{54}$ And there is no indication that constitutional objections were raised to the inclusion of a deadline in this fashion. To be fair, though, the practice of placing ratification deadlines in a joint resolution was relatively brief and came at a time when the limits on Congress from enumeration were taken less seriously than they are today. ${ }^{55}$ (Congress has not sent an Article V amendment to the states since 1978, so there is no relevant practice since then.) As a result, nothing bars Congress from concluding that there was no legislative authority to impose the ERA's time limit in the first place and declaring the expired deadline null and void. ${ }^{56}$

Nevertheless, the argument that Congress lacks the power to impose a ratification time limit through a joint resolution is not convincing. Recent Supreme Court decisions that read the Constitution's enumerated powers more rigorously do so largely to protect state sovereignty and prevent Congress from assuming a police power. ${ }^{57}$ Imposing a deadline on the ratification of an Article $\mathrm{V}$ amendment is, by contrast, a narrow exercise of authority that does not raise the prospect of a slippery slope towards a police power. Nor is state sovereignty affected by such a requirement. The states are free to ratify proposed amendments after a congressional deadline expires, as Nevada and Illinois have done with the ERA. More important, state sovereignty is more constrained in the Article V process than in other contexts, as Congress selects the mode of state ratification (legislatures or conventions) and the text of the proposal that the states may vote

\footnotetext{
${ }^{54}$ See infra text accompanying note 56.

${ }^{55}$ See United States v. Lopez, 514 U.S. 549, 567-68 (1995) (launching a new era of judicial scrutiny for enumerated powers).

${ }^{56}$ In other words, if Congress decides to waive the ERA's ratification deadline, that could be done on the ground that using a joint ratification to impose one was not valid, rather than on the ground that Congress is free to change such deadlines.

${ }^{57}$ See Nat'1 Fed'n of Indep. Bus. v. Sebelius, 567 U.S. 519, 534-36 (2012); United States v. Morrison, 529 U.S. 598, 615-19 (2000); Lopez, 514 U.S. at 564.
} 
on. ${ }^{58}$ Thus, there is no solid ground for rejecting Congress's implied power to impose a time limit on the states via a joint resolution.

\section{B. The Textual Argument for Authority to Change a Deadline}

The next question is whether the text of Article V and some of the constitutional amendments support Congress's authority to change a time limit for ratification and, if so, when? An obvious difference between the ERA and four other amendments that were adopted is that there is no ratification deadline in the text of the ERA itself. ${ }^{59}$ The Eighteenth, Twentieth, Twenty-First, and Twenty-Second Amendments each state that the text would be "inoperative" unless ratified within seven years. ${ }^{60}$ Beginning with the Twenty-Third Amendment, the sevenyear ratification timeframe was moved into the joint resolution Congress proposed alongside the amendment. ${ }^{61}$ While the reason for this switch is not clear, ${ }^{62}$ the placement of the deadline in the ERA's joint resolution was part of the rationale for the extension of its ratification deadline by Congress in $1978 .{ }^{63}$ Joint resolutions, of course, can be amended or repealed by Congress just like ordinary statutes. ${ }^{64}$

\footnotetext{
${ }^{58}$ See, e.g., Hawke v. Smith, 253 U.S. 221, 230 (1920) (“[T]he power to ratify a proposed amendment to the federal Constitution has its source in the federal Constitution. The act of ratification by the state derives its authority from the federal Constitution to which the state and its people have alike assented.")

${ }^{59}$ See H.R.J. Res. 208, 92d Cong., 2d Sess., 86 Stat. 1523 (1972).

${ }^{60}$ See supra note 23. Prior to the Eighteenth Amendment, no ratification time limits were imposed on Article V proposals. See Dillon v. Gloss, 256 U.S. 368, 371-72 (1921).

${ }_{61}^{6}$ See S.J. Res. 7, 92nd Cong., 1st Sess., 85 Stat. 825 (1971) (Twenty-Sixth Amendment proposal); S.J. Res. 1, 89th Cong., 1st Sess., 79 Stat. 1327 (1965) (Twenty-Fifth Amendment proposal); S.J. Res., 87th Cong., 2nd Sess., 76 Stat. 1259 (1962) (Twenty-Fourth Amendment proposal); S.J. Res. 39, 86th Cong., 2nd Sess., 74 Stat. 1057 (1960) (Twenty-Third Amendment proposal).

${ }^{62}$ Style is the most likely explanation. Congress may have wanted to avoid the inclusion of text that would become superfluous once a constitutional amendment was ratified. See Rees, supra note 25, at 918 (quoting Noel Dowling, a Columbia Law School Professor, who gave this reason for the change when the Twenty-Third Amendment was proposed). There is no indication that Congress moved ratification deadlines to joint resolutions so that they could be amended.

${ }^{63}$ See KYVIG, supra note 3, at 414-15; Ginsburg, supra note 25, at 923-24; Held, Herndon \& Stager, supra note 5, at $128-30$.

${ }^{64} \mathrm{Cf}$. Held, Herndon \& Stager, supra note 5, at 130 ("As the proposing clause is merely legislative, the time limit can be changed if Congress exercises its power to adjust, amend, or extend its own legislative action with new legislative action.").
} 
The argument that Congress cannot alter a ratification deadline in a joint resolution for an Article $\mathrm{V}$ amendment would mean that there is no difference between including that limit in a joint resolution or in an amendment. To say that putting something into a proposed Article $\mathrm{V}$ amendment as opposed to elsewhere is meaningless is a strange notion for a textualist. Indeed, Congress implicitly rejected that idea in 1978 when proposing an Article V amendment to give the District of Columbia voting members in the Senate and in the House of Representatives. ${ }^{65}$ This representation proposal (which was not ratified by the states) was made while the ERA extension was pending and was changed to place the ratification deadline into the amendment itself to make clear that the ratification period could not be altered by Congress. ${ }^{66}$ The text of the ERA also implicitly rejects a reading holding that the placement of a deadline in the text of the amendment is immaterial. ${ }^{67}$ Section Three states that the ERA will not take effect until two years after ratification. ${ }^{68}$ This transition period indicates that Congress was quite capable of including timetables in the text of the amendment, thus barring a subsequent Congress from changing them without a new Article V amendment proposal. With respect to the ratification deadline, though, Congress declined to do so.

The leading counterargument is that joint resolutions prefacing a constitutional amendment are different because they are enacted pursuant to Congress's Article V power and hence need the same supermajorities that are necessary to send an amendment to the states for

\footnotetext{
${ }^{65}$ See H.R.J. Res. 554, 95th Cong., 2d Sess., 92 Stat. 3795 (1978).

${ }^{66} \mathrm{See}$ id. ("Sec. 4. This article shall be inoperative, unless it shall have been ratified as an amendment to the Constitution by the legislatures of three-fourths of the several States within seven years from the date of its submission."); id. (providing in the Joint Resolution that the D.C. Representation Amendment would be valid "when ratified by the legislatures of three-fourths of the several States within seven years from the date of its submission by the Congress"); see also KYVIG, supra note 3, at 421 (quoting the House Judiciary Committee Report, which stated that "[t]he effect of placing this time limit in the text of the amendment prohibits subsequent Congresses from deciding to extend the time allowed for ratification").

${ }^{67}$ See Held, Herndon \& Stager, supra note 5, at 129-30.

${ }^{68}$ See supra text accompanying note 1.
} 
ratification. ${ }^{69}$ At most, though, this means that Congress can change such a joint resolution, but only if more than two-thirds of each House concurs. ${ }^{70}$ An even stronger view is that such an extension would wipe out prior state ratifications and reset the total to zero. ${ }^{71}$ But that claim collapses the distinction between including a ratification deadline in a joint resolution instead of the amendment's text. In other words, Congress is free to propose an Article V amendment a second time (as was attempted with the ERA in 1983).$^{72}$ If that succeeds, then the new proposal would start with zero state ratifications. Holding that a ratification deadline extension does the same thing would mean there is no difference between an extension and a full-blown second proposal. Maintaining that a supermajority in each House is required for an extension but that an extension does not nullify prior state ratifications at least preserves the distinction between the joint resolution and the text while also acknowledging that Article $\mathrm{V}$ joint resolutions are unique.

When the inquiry turns to Article V itself, there is no support for the proposition that ratification timetables require a two-thirds vote in each House of Congress. The only procedure mentioned in Article $\mathrm{V}$ is the mode of ratification, with the choices being state legislatures or state ratifying conventions. ${ }^{73}$ Congress has always mustered more than a two-thirds vote for the ratification mode and placed that detail in a joint resolution rather than in the text of a proposed amendment. ${ }^{74}$ Whether a supermajority is required for the ratification mode need not be

\footnotetext{
${ }^{69}$ See Ginsburg, supra note 25, at 928; see also Idaho v. Freeman, 529 F. Supp. 1107, 1150-53 (D. Idaho 1981), vacated as moot by Nat'l Org. for Women, Inc., v. Idaho, 459 U.S. 809 (1982).

${ }^{70}$ Rees, supra note 25, at 924.

${ }^{71}$ See Paulsen, supra note 11 , at 726.

72 See supra note 27 and accompanying text.

${ }^{73}$ See U.S. CONST. art. V (stating that "one or the other Mode of Ratification may be proposed by the Congress").

${ }^{74}$ See Magliocca, supra note 4, at 44-45 (citing 1 Jonathan Elliot, The Debates In the SEVERAL StATE CONVENTIONS ON THE AdOPTION OF THE FEDERAL CONSTITUTION, AS RECOMMENDED BY THE GENERAL CONVENTION AT PHILADELPHIA, IN 1787, at 338 (1888)) (quoting the joint resolution that prefaced the constitutional amendments proposed by the First Congress); see also S.J. Res. 7, 92d Cong., 85 Stat. 825 (1971) (Twenty-Sixth Amendment proposal); S.J. Res. 1, 89th Cong., 79 Stat. 1327 (1965) (Twenty-Fifth Amendment proposal); S.J. Res., 87th Cong., 76 Stat. 1259 (1962) (Twenty-Fourth Amendment proposal); S.J. Res. 39, 86th Cong., 74 Stat. 1057 (1960) (Twenty-Third Amendment proposal); H.J. Res. 27, 80th Cong., 1st Sess. (1947) (Twenty-Second Amendment proposal); S.J. Res. 211, 72d Cong., 47 Stat. 1625 (1933) (Twenty-First Amendment proposal); S.J.
} 
addressed here. The point is that there is nothing in the text of Article V that supports such a special rule for a ratification timeframe, in part because the Framers did not contemplate that proposed amendments would have a ratification deadline.

\section{Congressional Practice Under Supreme Court Doctrine}

Another flaw in the argument that ratification deadlines in a joint resolution may not be changed or may be changed only by a two-thirds vote in each House is that Congress changed the ratification period of the ERA by a majority vote. ${ }^{75}$ The degree to which Congress should be bound by its own precedents is undertheorized when compared to the issue of stare decisis for courts ${ }^{76}$ but the most straightforward approach is to treat a prior relevant congressional action as creating a presumption of validity that a subsequent Congress can reject. This conclusion draws on the Supreme Court's reasoning in Coleman, which explained that two aspects of the Article V process present political questions for Congress.

In Coleman, the Supreme Court held that Congress was the final authority on whether a proposed constitutional amendment could still be ratified when no time limit was included in the

Res. 14, 72nd Cong., 47 Stat. 745 (1932) (Twentieth Amendment proposal); H.R.J. Res. 1, 66th Cong., 41 Stat. 362 (1919) (Nineteenth Amendment proposal); S.J. Res. 17, 65th Cong., 40 Stat. 1050 (1917) (Eighteenth Amendment proposal); H.R.J. Res. 39, 62d Cong., 37 Stat. 646 (1912) (Seventeenth Amendment proposal); S.J. Res. 40, 61st Cong., 36 Stat. 184 (1909) (Sixteenth Amendment proposal); H.R.J. Res. 14, 40th Cong., 3d Sess., 15 Stat. 346 (1869) (Fifteenth Amendment proposal); H.R.J. Res. 48, 39th Cong., 1st Sess., 14 Stat. 358 (1866) (Fourteenth Amendment proposal); H.R.J. Res. 11, 38th Cong., 2d Sess., 13 Stat. 567 (1865) (Thirteenth Amendment proposal); H.R.J. Res., 8th Cong., 1st Sess., 2 Stat. 306 (1803) (Twelfth Amendment proposal); H.R.J. Res. 8, 3d Cong., 1st Sess., 1 Stat. 402 (1794) (Eleventh Amendment proposal). The First Congress established the precedent for designating the mode of state ratification in the joint resolution rather than in the text of a proposed Article $\mathrm{V}$ amendment. See MAGLIOCCA, supra note 4, at 44-45.

75 See Ginsburg, supra note 25, at 929; see also KYVIG, supra note 3, at 415 (listing the vote totals in the House of Representatives and in the Senate).

76 See Mark Tushnet, Legislative and Executive Stare Decisis, 83 NOTRE DAME L. REV. 1339, 1341-50 (2008). Tushnet's article is one of the few that discuss on how precedent should operate within Congress, whereas there are many articles on the issue for the courts. See, e.g., Richard H. Fallon, Jr., Stare Decisis and the Constitution: An Essay on Constitutional Methodology, 76 N.Y.U. L. REV. 570, 570-73 (2001); Henry Paul Monaghan, Stare Decisis and Constitutional Adjudication, 88 CoLUM. L. REV. 723, 724 (1988). 
text of that amendment. ${ }^{77}$ The case concerned the Child Labor Amendment, which was proposed by Congress in 1924 (without a ratification deadline in the amendment's text or in its joint resolution) but was never ratified. ${ }^{78}$ On the issue of whether too much time had passed for the states to ratify the amendment, the Court stated:

[T] he question of a reasonable time in many cases would involve, as in this case it does involve, an appraisal of a great variety of relevant conditions, political, social and economic, which can hardly be said to be within the appropriate range of evidence receivable in a court of justice. ${ }^{79}$

"On the other hand," the Court added:

[T]hese conditions are appropriate for the consideration of the political departments of the Government. The questions they involve are essentially political and not justiciable. They can be decided by the Congress with the full knowledge and appreciation ascribed to the national legislature of the political, social and economic conditions which have prevailed during the period since the submission of the amendment. ${ }^{80}$

Thus, "the Congress in controlling the promulgation of the adoption of a constitutional amendment has the final determination of the question whether by lapse of time its proposal of the amendment had lost its vitality prior to the required ratifications." 81

77 Coleman v. Miller, 307 U.S. 433, 456 (1939). Four Justices took the view that the Article V "process itself is 'political' in its entirety, from submission until an amendment becomes part of the Constitution, and is not subject to judicial guidance, control or interference at any point." Id. at 456, 459 (Black, J., concurring). Chief Justice Hughes wrote the opinion of the Court, which was joined by only two other Justices, which addressed the justiciability of only the specific issues raised in the litigation. Id. at 435, 446-56 (majority opinion).

78 See Gerard N. Magliocca, Court-Packing and the Child Labor Amendment, 27 CONST. COMMENT. 455, 457-61 (2011) (providing an overview of the debate on that amendment).

79 Coleman, 307 U.S. at 453. The contrary view, expressed in Dillon v. Gloss, that the question of a reasonable time was justiciable was dismissed as dictum. See id. at 452-53.

$80 \quad$ Id. at 454 .

81 Id. at 456; see Held, Herndon \& Stager, supra note 5, at 130-31 (citing Coleman to support the argument that Congress may waive the ERA ratification deadline). 
Coleman yields two relevant lessons for the ERA. One is that Congress is charged with deciding if a proposed Article $\mathrm{V}$ amendment can still be ratified by the states so long as the amendment itself contains no ratification deadline. This was the understanding that Congress relied on in declaring the Twenty-Seventh Amendment part of the Constitution, even though more than two centuries had passed since the First Congress made the proposal. ${ }^{82}$ The other is that the Supreme Court is very unlikely to second-guess Congress's construction of its Article V authority. ${ }^{83}$ For the ERA, Congress's construction was that a ratification deadline in a joint resolution can be modified by a majority vote. Congress can rely on that precedent to waive the ERA's ratification deadline via a simple majority. ${ }^{84}$

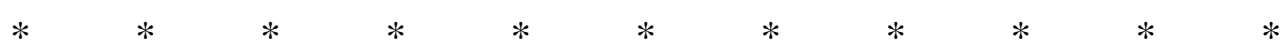

If Congress chooses to waive the ERA's ratification deadline, then the appropriate form for that action would be a joint resolution much like the one used to extend the deadline in 1978. Like other joint resolutions, this hypothetical one would be subject to a filibuster (requiring sixty

82 Coleman, 303 U.S. at 454-56. There is also a valid argument (that I need not address here) that the ratification of the Twenty-Seventh Amendment was self-executing, given that there was no ratification deadline in the proposal made by the First Congress.

83 Coleman, 303 U.S. at 456. Let me briefly discuss the vitality of Coleman given the retreat of the political question doctrine since the 1930s. See, e.g., Rachel E. Barkow, More Supreme Than Court? The Fall of the Political Question Doctrine and the Rise of Judicial Supremacy, 102 COLUM. L. REV. 237, 263-73 (2002); see also Baker v. Carr, 369 U.S. 186, 232-34 (1962) (rejecting the political question doctrine in the context of legislative apportionment). Questions pertaining to the Article V process present an especially compelling case for nonjusticiability given the conflict of interest that is often present for courts. Some proposed amendments are expressly intended to overrule a Supreme Court decision See U.S. CONST. amend XIV, § 1 (overruling Scott v. Sandford, 60 U.S. 393, 427 (1857) by declaring that all persons born in the United States (including AfricanAmericans) were citizens of the United States). Thus, permitting the Court to rule on the validity of the process used to ratify an amendment could be seen as an attempt to thwart the prerogative of "We the People" to assert their constitutional sovereignty. In any event, the Court has displayed no interest in revisiting Coleman, in spite of the ratification or proposal of many Article V amendments since 1939.

84 Congress could decide to reject the 1978 precedent and require a greater than two-thirds vote to waive the ratification deadline. In practice, this could occur if Congress applies the same supermajority threshold to a vote on rejecting the five state rescissions of the ERA as part of a deadline extension. See infra notes 113, 115-16 and accompanying text; see also supra note 1 and accompanying text. 
votes to end debate) absent a change to the Senate's rules or practices. ${ }^{85}$ And consistent with the omission of any reference to the Executive Branch in Article V and with longstanding tradition, the President would not need to sign and could not veto such a resolution. ${ }^{86}$ Congress could act before three-fourths of the states ratify the ERA or wait until that magic number is met. But how will Congress know if thirty-eight states have ratified the amendment? This question is usually simple arithmetic, but not for the ERA.

\section{PART III-THE PROBLEM OF STATE RESCISSIONS}

This Part considers whether Congress should count--as part of the three-quarters total required by Article V-five states that ratified the ERA but later rescinded those votes. There is virtually no doubt that Congress can count these states as "yes" votes, as Coleman held that state ratification rescissions also present a political question. ${ }^{87}$ Whether Congress should take that step and, if so, by what voting rule, is a far more complicated question that encapsulates the dilemma presented by the ERA's undead status: Is it dirty pool for Congress to make this amendment part of the Constitution in the presence of state rescissions and a long-expired ratification deadline? The answer is a qualified yes, which leads to my view that Congress should not count the five rescinding states in the yes column. If Congress decides that they should be counted, then that

85 See U.S. Senate Comm. On Rules and Admin., Standing Rules of the Senate, S. Doc. No. 110-9, at 15-17 (2007) (Rule XXII(2)) (stating that cloture may be invoked with sixty votes on "any measure, motion, other matter pending before the Senate"). No attempt was made to filibuster the extension of the ERA's ratification deadline in 1978, but that may just reflect the fact that Senate filibusters were less common then.

86 See, e.g., Jimmy Carter, Remarks on Signing H.J. Res. 638, in 2 PUBLIC PAPERS OF THE PRESIDENTS OF THE UNITED STATES, 1800, 1800-01 (1979) (“As is well known, the Constitution does not require that the President sign a resolution concerning an amendment to the Constitution of the United States."). The view that the President plays no role in the Article V process dates back to a statement from Justice Samuel Chase during oral argument in a 1798 Supreme Court case, see Hollingsworth v. Virginia, 3 U.S. 378, 381 n* (1798), though one could say that President Washington established the custom during the First Congress when what became the Bill of Rights was proposed with no formal action by him.

$87 \quad$ See Coleman, 303 U.S. at 450. 
should be done by only a greater than two-thirds vote in the House of Representatives and in the Senate, in line with past practice.

\section{A. The Reconstruction Precedent}

There is scant authority on whether a state can withdraw its ratification of an Article V amendment. ${ }^{88}$ Neither Congress nor the Supreme Court recognizes the right of a state to rescind ${ }^{89}$ though Congress has accepted the right of a state to ratify an amendment after previously voting no. ${ }^{90}$ During Reconstruction, Congress expressed its disapproval for an unqualified right of rescission, ${ }^{91}$ but a review of that action reveals that many questions were left unanswered. Article V precedents from Reconstruction must be taken with a grain of salt due to the special constitutional conditions that immediately followed the Civil War, ${ }^{92}$ but the attempted

88 During the ratification debate on the original Constitution, James Madison told Alexander Hamilton that the "Constitution requires an adoption in toto and for ever. It has been so adopted by the other states." See Jung, supra note 8, at 240 (quoting Letter from Alexander Hamilton to James Madison (July 19, 1788), reprinted in 5 THE PAPERS OF AlEXANDER HAMiLTON 177-78 (H. Syrett ed. 1962). But this statement was in response to Hamilton's question about whether a state could ratify the Constitution conditionally under Article VII and then withdraw if the conditions went unmet. See id. Nothing in Madison's letter speaks to the issue of whether a state can withdraw its assent to a constitutional amendment prior to final ratification.

89 During the 1920s, Congress considered but did not propose an amendment to Article Five that would have, among other things, expressly permitted a state to rescind its ratifications of a proposal. See KYVIG, supra note 3, at 251-53.

90 Some ex-Confederate States initially rejected the Fourteenth Amendment but then decided to ratify and were counted in the final tally. See Coleman, 307 U.S. at 448 (observing that Georgia, North Carolina, and South Carolina rejected the proposal in 1866 but voted to ratify in 1868). The ratification of the Constitution itself also supports the proposition that a state can give its consent after formally refusing. In 1788, Rhode Island rejected the Constitutional Convention's proposal in a referendum, see PAUline MAIER, RATIFICATION: THE PEOPLE DEBATE THE CONSTITUTION, 1787-1788, at 223-24 (2010), but two years later the state convened a ratifying convention and reversed that decision. See id. at 458-59.

91 See Coleman, 307 U.S. at 449-50. Senator Charles Sumner argued that a state could not withdraw its ratification of an amendment by analogy to a state's lack of a right to secede from the Union, see CONG. GLOBE, 40th Cong., 2d Sess. 1142, 1145 (1868) (statement of Sen. Sumner), but these situations can be easily distinguished.

92 See GERARD N. MAGLIOCCA, AMERICAN Founding Son: JoHn Bingham AND the INVENTION OF THE FOURTEENTH AMENDMENT 109-11 (2013). For example, senators and representatives of the ex-Confederate States were excluded from the portion of the Thirty-Ninth Congress that proposed the Fourteenth Amendment. Likewise, Congress imposed upon those states the requirement that they ratify the Fourteenth Amendment as a condition for readmission. For an overview of these events, see $i d$. at 109-11, 129-30. 
rescissions in that era are the best starting point for a constitutional analysis because they are the only concrete examples and because they were discussed in Coleman. ${ }^{93}$

The first states that sought to retract ratification votes did so for the Fourteenth

Amendment. Ohio and New Jersey ratified the proposal early on, but Democratic victories in the 1867 elections led the new state legislatures in both states to rescind their ratifications. ${ }^{94}$ By July 1868, three-fourths of the states had ratified the Fourteenth Amendment if Ohio or New Jersey was counted as a yes. ${ }^{95}$ The Secretary of State, the official then tasked with formally recognizing the ratification of an Article $\mathrm{V}$ proposal, ${ }^{96}$ issued a proclamation stating that the status of the Fourteenth Amendment was unclear due to "doubt and uncertainty" about the two rescinding state resolutions. ${ }^{97}$ Congress responded with a concurrent resolution declaring the Fourteenth Amendment part of the Constitution and listing Ohio and New Jersey among the ratifying

\footnotetext{
$93 \quad$ See Coleman, 303 U.S. at $448-50$.

94 See 2 Bruce Ackerman, We The People: Transformations 218, 230 (1998); Magliocca, supra note 91 , at $140-44$.

$95 \quad$ See Coleman, 303 U.S. at 448-49; Paulsen, supra note 11, at 710.

9615 Stat. 706, 706-07 (1868). Today, the relevant official is the Archivist of the United States. 1 U.S.C. § 106(b) (2018). In theory, the Archivist could decide on his own that the ERA was ratified rather than deferring to Congress. See id. In practice, this sort of action would be a disaster. First, it is far from clear that the statute gives any discretion to the Archivist. Second, the Archivist is typically a librarian or a historian who is not expected to make legal decisions, especially of this magnitude. Third, if the Archivist acted on his own, then judicial review would probably be available to challenge his determination, which would not be the case if Congress concluded that the ERA was ratified.

$97 \quad 15$ Stat. at $706-07$.
} 
states. ${ }^{98}$ Unfortunately, Congress did not explain this decision in the resolution or in the brief floor debate that preceded approval. ${ }^{99}$

Congress's silent decision to reject the state rescissions leaves open the possibility that some right to rescind exists. There is no way to know if Congress intended to lay down a broad rule against state rescissions or one that was tailored to the specific circumstances of the Fourteenth Amendment (for example, its perceived necessity as a settlement of the Civil War). ${ }^{100}$ In Coleman, the Court explained only that "the political departments of the Government dealt with the effect both of previous rejection and of attempted withdrawal and determined that both were ineffectual in the presence of an actual ratification." 101 And "[ $\mathrm{t}]$ his decision by the political departments of the Government as to the validity of the adoption of the Fourteenth Amendment has been accepted." 102 Coleman concluded:

We think that in accordance with this historic precedent the question of the efficacy of ratifications by state legislatures, in the light of previous rejection or attempted withdrawal, should be regarded as a political question pertaining to the political

98 Id. at 710; see Coleman, 303 U.S. at 449. The rescission issue was actually moot. Before the concurrent resolution was passed, Georgia ratified and gave the Fourteenth Amendment the three-fourths total without Ohio and New Jersey. Paulsen, supra note 11, at 710-11. Though the House of Representatives was informed of Georgia's action via telegram, the Speaker expressed doubt that this constituted a formal notice of ratification and thus Georgia's vote was not recorded. CONG. GLOBE, 40th Cong., 2d Sess. 4296 (1868) (statement of Speaker Colfax) ("The Chair doubts whether this is an official notice such as is required. It should be sent by mail.") When the Secretary of State issued his final proclamation on the Fourteenth Amendment one week later, he counted Georgia, Ohio, and New Jersey as votes for ratification. 15 Stat. at 710-11; Coleman, 303 U.S. at 449.

See 15 Stat. at 710; Cong. Globe, 40th Cong., 2d Sess. 4296.

100 The only other state rescission prior to the ERA came when New York repealed its ratification of the proposed Fifteenth Amendment. See Coleman, 307 U.S. at 449 n.25; KYVIG, supra note 3, at 182. In this case, though, Congress made no statement about the rescission. Instead, the Secretary of State issued a proclamation declaring the Fifteenth Amendment part of the Constitution and counting New York as a yes vote. 16 Stat. 1131 (1870). The Fifteenth Amendment had more than the three-fourths vote required without New York, so the issue was moot. See Coleman, 307 U.S. at 449 n.25.

$101 \quad$ Coleman, 307 U.S. at 449.

$102 \quad I d$. at $449-50$. 
departments, with the ultimate authority in the Congress in the exercise of its control over the promulgation of the adoption of the amendment. ${ }^{103}$

One aspect of the Fourteenth Amendment precedent that does not receive sufficient attention is that Congress rejected the rescissions by a greater than two-thirds vote. In the House of Representatives, the vote on the part of the resolution that counted Ohio and New Jersey as votes for ratification was 127 to $33 .{ }^{104}$ In the Senate, the concurrent resolution was adopted without objection, which was tantamount to a unanimous vote. ${ }^{105}$ Nobody contended that a supermajority was required to reject a state rescission, but the results were consistent with that voting rule. ${ }^{106}$ And, as I shall explain in a moment, there are sound practical reasons for Congress to read its Reconstruction precedent as requiring a supermajority margin. ${ }^{107}$

\section{B. The Special ERA Rescission Problem}

Setting aside this limited authority, why should a state be unable to change its mind on ratifying an Article $\mathrm{V}$ amendment from yes to no? ${ }^{108}$ The best answer is that finality is important in the Article $\mathrm{V}$ process. If a state can rescind, then there would be no reliable count of the floor of state ratifications. A state could also rescind its ratification once three-fourths of the states ratify, which in the ERA's case could throw the question of final ratification into confusion if the ratification waiver debate is underway. Or perhaps the thought is that states will just take their

\footnotetext{
$103 \quad$ Id. at 450 .

104 See Cong. GlobE, 40th Cong., 2d Sess. 4296.

$105 \quad$ See id. at 4295.

106 See generally id. at 4296 (finding no discussion of supermajority in the House debate record).

107 See infra text accompanying notes 112-15.

108 One textual argument is that Article V refers only to state ratifications, not rejections. See Held, Herndon \& Stager, supra note 5, at 131-32. Thus, a state can ratify an amendment after a rejection, but not the opposite. Id. This argument, however, begs the question of what ratification means. Is a state ratification final or can that be reversed under state law?
} 
decision to ratify more seriously if a yes vote is final. ${ }^{109}$ Finality is, of course, an important consideration in many legal contexts even if imposing finality works an injustice (for example, statutes of limitation). To say, though, that finality should preclude rather than just caution a state from rescinding a vote for ratification is a difficult proposition to maintain.

A categorical argument against state rescission is especially hard to make for the ERA because finality cannot be essential for state ratifications yet dispensable for the ratification deadline. ${ }^{110}$ If there were no ratification deadline for the ERA, as there was none for the Fourteenth Amendment, then a congressional decision to reject state rescissions for finality reasons would be defensible. ${ }^{111}$ In this instance, though, by waiving the ratification deadline, Congress would be denying that finality is a decisive factor. To do so while simultaneously declaring that finality precludes a state from rescinding a ratifying vote would be inconsistent and cast a shadow on the ERA's legitimacy. No convincing distinction exists between how finality should operate with respect to Congress and state legislatures, who are co-equal partners in the Article V process. ${ }^{112}$ More importantly, even if a distinction could be cobbled together, many people may dismiss the claim as result-driven or partisan.

South Dakota's rescission of its ERA ratification demonstrates a related finality argument. Unlike the other four rescinding states, South Dakota did so in protest of Congress

\footnotetext{
${ }^{109}$ See id. at 133. I should note that there is no allegation, other than the Kentucky example discussed earlier, see supra note 7 , that the rescinding states used an invalid procedure at the state level.

${ }^{110}$ See Held, Herndon \& Stager, supra note 5, at 117 (noting Congress's extension of the ratification deadline for the ERA).

${ }^{111}$ Id. at 123 ("The first time limit imposed on the ratification of a constitutional amendment was in ... the Eighteenth Amendment .....")

112 See Paulsen, supra note 11, at 731 ("Within broad bounds, then, a state should be free to determine, as a matter of its own law, the procedures governing its own legislative processes . . . and this freedom should extend to amendment ratification issues.").
} 
extending the ratification deadline without any clear recognition that the states could rescind. ${ }^{113}$

The South Dakota resolution stated, in pertinent part:

[I]f the Congress of the United States ex post facto can unilaterally alter the terms and conditions under which a proposed amendment to the Constitution of the United States is submitted to the several states for ratification, in the absence of a clear determination of the ability of a state legislature to rescind a previous ratification, the effect will be to inhibit state legislatures from acting promptly on any proposed amendment for fear of transferring the power to amend the Constitution of the United States to a small minority of the several states, and, perhaps, even a small minority of several generations . . . ${ }^{114}$

Likewise, the state resolution stated:

[T]he opinion that the Congress of the United States ex post facto has the power to unilaterally alter the terms and conditions under which it submits proposed amendments to the Constitution of the United States would necessarily inhibit debate on the merits of the proposed amendments and force each legislature to consider the probability and timing of the possible ratification of other state legislatures because of the uncertainty caused by the perpetual possibility of a sudden change in the Constitution of the United States due to a shift of opinion in a small number of states .... ${ }^{115}$

South Dakota did not contend that Congress lacked the power to alter the ratification deadline and disregard any state rescissions. The point was just that doing both was simply unfair.

Another way of explaining the same idea is that Article V can tolerate only so much procedural creativity. A decision by Congress to ignore the state rescissions and waive the expired deadline would leave opponents of the ERA feeling cheated to an extent that would not be true if only one or the other was done. ${ }^{116}$ Many Americans would be convinced that the ERA was not "really" part of the Constitution. Some states and private parties might respond by

\footnotetext{
113 See S.J. Res. 2, 54th Leg. Assemb., Reg. Sess. (S.D. 1979).

$114 \quad$ Id.

$115 \quad$ Id

116 Congress may conclude that waiving the ERA's ratification deadline would be illegitimate by itself. My only point here is that doing that and disregarding the state rescissions is worse.
} 
questioning the legitimacy of ratification in litigation on the Twenty-Eighth Amendment. There could be judges who would respond by giving the narrowest possible reading to the ERA given its dubious status. ${ }^{118}$ Others will just ignore what they deem to be a phony constitutional amendment. ${ }^{119}$ None of this is good for the rule of law.

Even more disturbing is the possibility that another Congress might try to repeal the "illegitimate" recognition of the ERA. The finality interest is at its apex for the official acknowledgment that an amendment is part of the Constitution. Declaring that a provision is included in our higher law and then retracting that decision would be highly disruptive. Nevertheless, if Congress can by joint resolution declare the ERA ratified, then why can that decision not be repealed by a joint resolution? Finality does not provide as strong an answer as possible given that the amendment can be ratified only by rejecting finality for the ratification deadline. Moreover, the ERA states that its provisions do not take effect until two years after ratification. ${ }^{120}$ As a result, an attempted congressional repeal during that transitional period (basically, by the next Congress) would arguably not disturb any reliance interests that finality ordinarily protects. ${ }^{121}$

\section{Abstention or Supermajority}

118 See Denning \& Vile, supra note 12, at 598-600. Denning and Vile claim that the Twenty-Seventh Amendment received a miserly construction due to its unusual path to ratification, though I am not persuaded by that argument.

$119 \quad$ Id.

$120 \quad$ See supra text accompanying note 1.

121 Another lurking issue is that a state could attempt to rescind its ratification after three-fourths have ratified, but before Congress waives the deadline. My view is that a state can do this until Congress acts. After Congress recognizes the ERA as part of the Constitution, though, a state could not rescind and undo the ERA. 
The best way to avoid these tough hypotheticals and extended disputes is to craft a final recognition process that can satisfy the ERA's supporters and opponents. The best idea would be for Congress to wait until thirty-eight states other than the rescinding states ratify before taking up the issue of waiving the ERA's ratification deadline. The other thought would be to insistconsistent with the Fourteenth Amendment precedent—-that the rescissions may be disregarded only by more than a two-thirds vote in each House. ${ }^{122}$ Neither choice is stable, as one Congress cannot bind another on these topics, but either one is superior to holding that Congress should disregard the state rescissions and can do so with a majority in each House.

Given that Coleman concluded that state rescissions raise a political question, Congress can choose to tacitly acknowledge the ERA rescissions. This would mean that six more states, not one more, would be required to ratify the proposal for the total to reach thirty-eight. No action would be required - Congress could just ignore any petitions to waive the ratification deadline until six more states act. In this sense, there need be no formal recognition of the right to rescind. If and when thirty-eight non-rescinding states ratify, then Congress could just say in waiving the deadline that three-fourths of the states have ratified the ERA without listing the individual states and thus rendering a judgment on the validity of the five rescissions. ${ }^{123}$ Or Congress could choose at that time to accept or reject the rescissions. Either way, one cloud over the legitimacy of the ERA would be completely erased.

In the event that Congress exercises its authority to disregard the rescissions, then the next-best solution would be for Congress to use a two-thirds voting requirement for that action.

122 See Coleman v. Miller, 307 U.S. 443, 449-50 (1939).

123 Granted, the Fourteenth Amendment resolution did list the states that were counted as voting for ratification. See supra text accompanying note 97 . But it is hard to see why this sort of catalog is required when there is a consensus that thirty-eight have ratified. 
Such a rule would be in accord with the way that Congress addressed the issue in $1868 .{ }^{124}$

Furthermore, imposing a supermajority threshold on rejecting the rescissions would go a long way toward persuading skeptics that the ERA was not being rammed through Congress on a partisan basis or in a way that ignores states' rights. Meanwhile, critics of accepting (tacitly or not) a right to rescind will be able to reject the five state withdrawals in a fashion that does not clash with the past practice of Congress. This compromise will not please everyone. But consider that using a supermajority procedure for the waiver of the ratification deadline would contradict past practice (the extension of the ERA in 1978 by a majority). ${ }^{125}$ The best way to introduce a reassuring safeguard into the ERA's recognition process is at the rescission stage. ${ }^{126}$

In sum, the presence of state rescissions muddies the water on whether Congress should waive the ERA ratification deadline. To avoid a sharp blow to the ERA's legitimacy, Congress should tread carefully before deciding to reject the rescissions in the name of finality in addition to waiving the ERA's "final" ratification deadline.

\section{PART IV-WHEN THE BALL IS IN CONGRESS'S COURT}

This Part looks at what Congress might consider in assessing if the ERA ratification deadline ought to be waived if three-fourths of the states ratify. Part of the answer clearly turns

124 See supra text accompanying notes 97-103. There is a coordination problem here, in that neither House of Congress can dictate the rules of the other. See U.S. ConST. art. I, $\S 5$. The Senate and the House of Representatives would have to agree on the text of a joint resolution that expressly contained a supermajority standard, or the leadership in both parties would have to reach an informal understanding that the resolution would not be brought up in one body if the other did not vote by at least two-thirds in favor.

125 See supra text accompanying notes 74-75. A Senate filibuster of a joint resolution waiving the deadline would create a modest supermajority barrier, but the Senate can decide that the ERA resolution may not be filibustered.

126 In practice, insisting on a supermajority for rescission would probably mean that a supermajority would exist for waiving the ratification deadline (unless, of course, no action is taken on the ERA until thirty-eight nonrescinding states ratify). A Representative or a Senator who votes for rejecting the state rescissions is unlikely to turn around and vote against waiving the ERA's ratification deadline. 
on the views of individual members and their constituents about the merits of the amendment. It is a fool's errand to predict what those attitudes might be at some unknown date, ${ }^{127}$ so I will explore three other points. One is what the ERA would do if ratified. The substance of a proposed constitutional amendment cannot be completely divorced from the ratification process, especially in a doubtful case such as this. A second "X factor" is the degree to which originalism gains additional ground in the constitutional culture, which may make the ERA appear or be more necessary. Finally, I shall address whether Congress would, in essence, conclude that the ERA's expiration deadline should be treated as final due to stare decisis or reliance interests.

\section{A. What Would the ERA Accomplish?}

Canny politicians will probably think hard about what the ERA may mean — and what they may be blamed for-before they decide whether to waive the ratification deadline. This question poses a challenge because when ratification is under consideration, the law of sex equality will be very different from where the doctrine was in 1972 when the ERA was proposed and may be very different from where the law is now. The recent ratification debates in Nevada and Illinois, though, shed some light on what ERA supporters believe the proposal will do.

One recurring theme is that the ERA should be ratified mainly for symbolic reasons. Justice Ginsburg said in 2014 that she wanted the ERA in the Constitution partly because "I would like my granddaughters, when they pick up the Constitution, to see that notion - that women and men are persons of equal stature - I'd like them to see that is a basic principle of our society." ${ }^{128}$ Some legislators in Nevada also urged ratification on symbolic grounds. For

\footnotetext{
127 Consider, for example, how events such as the confirmation of Justice Kavanaugh to the Supreme Court can change public opinion on gender issues.

128 Nikki Schwab, Ginsburg: Make ERA Part of the Constitution, U.S. NEWS AND WoRLD REPORT (Apr. 18, 2014), https://www.usnews.com/news/blogs/washington-whispers/2014/04/18/justice-ginsburg-make-equal-rightsamendment-part-of-the-constitution; see H.R. TRANSCRIPTION DEBATE, 100th Gen. Assemb., Reg. Sess., at 323 (Ill. May 30, 2018) (statement of Rep. Welch) (quoting Justice Ginsburg on this point).
} 
instance, one Assemblywoman said that "[t]his resolution is symbolic and not in a bad way." 129 Another explained her support by noting:

[T]his Chamber is full of symbolism. On my left hand I wear a ring that symbolizes my promise to love, respect, and stay faithful to one man for the rest of my life. We stand underneath a seal that reminds us we are a Battle Born State and that Home Means Nevada, and we pledge allegiance to a flag every single day to celebrate the freedom that was so hard fought for. ${ }^{130}$

The idea that the Constitution is in part aspirational is not a new one, as the Preamble itself serves that purpose.

Another school of thought is that the ERA would force the Supreme Court to apply strict scrutiny to sex classifications and accept Congress's authority to enact more sweeping legislation on gender equality. Legislators in Nevada and Illinois both observed that under current doctrine intermediate scrutiny is the standard for reviewing gender distinctions. ${ }^{131}$ These ratifiers argued that the ERA would require the federal courts to apply strict scrutiny. ${ }^{132}$ One senator in Nevada argued that, under intermediate scrutiny, "discrimination based on sex can often be validated by basing such discrimination on long-held traditions," which she said would not be the case under strict scrutiny. ${ }^{133}$ An Illinois representative who made a similar claim also argued that the ERA

Assemb. JouRnAL, 79th Sess., at 310 (Nev. 2017) (statement of Assemb. Diaz).

130 Id. at 311-12 (statement of Assemb. Tolles); S. JouRnAL, 79th Sess., at 10 (Nev. 2017) (statement of Sen. Gansert) ("While this vote for the Equal Rights Amendment may be redundant because of the work done here in Nevada and other states, it is still a powerful symbol of the need for equality."); $i d$. (statement of Sen. Ratti) ("We have to figure out how to send a message to our young women that they are equal and that the world is available to them. I believe S.J.R. No. 2 sends them this message ....."); id. at 11 (statement of Sen. Segerblom) ("I think in some ways it is symbolic, but if this is the case, it is still important.").

$131 \quad$ See Craig v. Boren, 429 U.S. 190, 207-10 (1976).

132 See H.R. TRAnSCRIPTION Debate, 100th Gen. Assemb., Reg. Sess., at 342-44 (Ill. May 30, 2018) (statement of Rep. Stratton); id. at 331 (statement of Rep. Lang). In some instances, this point was raised as an objection to ratification. See id. at 312-15 (statement of Rep. Morrison). The Illinois Senate ratified the ERA without debate. 
would "give Congress a constitutional basis to enact legislation that targets gender violence and enhances the protections for victims" ${ }^{134}$ and thereby overrule United States v. Morrison. ${ }^{135}$

A third possible understanding of the ERA's scope is that the text would codify existing Supreme Court doctrine on sex equality, which is neither symbolic nor a change in the prevailing legal standard. ${ }^{136}$ There were some endorsements of this logic in the state ratification debates as well. For instance, two Illinois Representatives asserted that the ERA was necessary to "prevent a rollback" of the court's precedents. ${ }^{137}$ One of them pointed to the invalidation of Section Four of the Voting Rights Act in Shelby County v. Holder ${ }^{138}$ as proof for "why we must pass the Equal Rights Amendment." 139 In Nevada, a related point made was that "[t]here is a difference between relying upon other amendments and legal interpretation of laws by courts, as opposed to ensuring a constitutional right to [sex] equality." 140

By the time Congress takes up the ratification-deadline waiver, the ratification of the ERA may be construed as requiring heightened scrutiny for related legal distinctions. Three federal circuit courts have held that the word "sex" in Title VII of the Civil Rights Act of 1964

134 H.R. TransCRIPTION Debate, 100th Gen. Assemb., Reg. Sess., at 342 (Ill. May 30, 2018) (statement of Rep. Stratton).

$135 \quad 529$ U.S. 598 (2000).

136 Parts of the Bill of Rights can be understood as codifying common-law rights. See MAGLIOCCA, supra note 4 , at 45 (quoting the joint resolution proposing the first set of amendments, which described them as "declaratory and restrictive clauses").

137 See H.R. Transcription Debate, 100th Gen. Assemb., Reg. Sess., at 311 (Ill. May 30, 2018) (statement of Rep. Fine); id. at 294 (statement of Rep. Anderson).

$138 \quad 570$ U.S. 529 (2013).

139 H.R. Transcription Debate, 100th Gen. Assemb., Reg. Sess., at 311 (Ill. May 30, 2018) (statement of Rep. Ammons).

140 S. Journal, 79th Sess., at 9 (Nev. 2017) (statement of Sen. Cannizzaro). 
should be construed as covering workplace discrimination based on either sexual orientation or transgender status. ${ }^{141}$ These decisions may not survive Supreme Court review, but if they do, then does that mean that the ERA's statement that "equality of rights under the law shall not be denied or abridged by the United States or by any State on account of sex"142 should be interpreted to incorporate sexual orientation and transgender people? This was not how the proposed amendment was understood by its supporters in 1972, but there could be a different view if and when three-fourths of the states ratify.

The takeaway is that many members of Congress may make their decision on waiving the ratification deadline based on what they think the ERA is. In other words, if this Twenty-Eighth Amendment is seen as symbolic or as a codification of existing precedent on sex discrimination, then one would expect greater support in Congress. ${ }^{143}$ The ERA would then look more like the Twenty-Seventh Amendment, which was very narrow in scope and hence something that was deemed acceptable for ratification even though more than two centuries had elapsed since its proposal. If, on the other hand, the ERA is understood as making more sweeping changes to existing doctrine, then the fairness concerns about waiving the ratification deadline will loom larger, either in reality or as an excuse for those who do not support those changes.

An additional wrinkle is that the unique circumstances surrounding the ERA's final ratification provide Congress with an opportunity to make its views known on which of these

141 See, e.g., Equal Opportunity Employment Comm'n v. R.G. \& G.R. Harris Funeral Homes, Inc., 884 F.3d 560, 571 (6th Cir. 2018) (transgender identity); Zarda v. Altitude Express, Inc., 883 F.3d 100, 108 (2d Cir. 2018) (en banc) (sexual orientation); Hively v. Ivy Tech Cmty. Coll. of Ind., 853 F.3d 339, 340-41 (7th Cir. 2017) (en banc) (sexual orientation).

$142 \quad$ See source cited supra note 1 and accompanying text.

143 The opposite view is possible. A member of Congress might conclude that waiving the ratification deadline is warranted only if the ERA will make a substantial change in the law. I am not convinced that most people will take that position. 
various interpretations is best. A joint resolution waiving the ratification deadline could state the understanding upon which Congress made its decision. While there is no precedent for Congress to offer substantive comments on the meaning of an Article V amendment at the formal recognition stage, there is no obvious reason why Congress could not do so when the recognition choice is complicated. What persuasive authority that sort of congressional statement would have in the courts is unclear. But a qualification or clarification of the ERA's meaning may persuade skeptical members to support a ratification deadline waiver.

\section{B. Originalism and Ratification}

Another external force that may influence Congress in assessing whether to waive the ratification deadline is how the ERA relates to the authority of originalism in constitutional interpretation. There is a symbiotic relationship between the ERA and the constitutional zeitgeitz within the Supreme Court with respect to originalism. They thrive together and suffer together, and at the moment both are on the upswing.

The weakness of originalism when the ERA was under consideration in the 1970s hindered ratification. Opponents of the ERA argued that the amendment was not needed because of the Supreme Court's recent "living constitutionalism" decisions applying Fourteenth Amendment heightened scrutiny to sex classifications. ${ }^{144}$ If the Court had adhered to an originalist view of the Equal Protection Clause that excluded women from heightened scrutiny, then the ERA may well have been ratified to satisfy the popular hunger for constitutional sex equality. ${ }^{145}$ An Article $\mathrm{V}$ amendment, of course, is one way of changing the Constitution when

$144 \quad$ See Siegel, supra note 24, at 1403-06.

145 On this score, one critical discussion came from Justice Powell's concurrence in Frontiero v. Richardson. See Frontiero v. Richardson, 411 U.S. 677, 692 (1973) (Powell, J., concurring). In contrast to Justice Brennan's plurality opinion, holding that sex distinctions should receive strict scrutiny, id. at 688 (plurality opinion), Justice Powell wrote, "[b]y acting prematurely and unnecessarily, as I view it, the Court has assumed a decisional responsibility at the very time when state legislatures, functioning within the traditional democratic process, are 
the Court will not. Originalism, however, did not command the support within the Court in the 1970s that developed in subsequent decades. ${ }^{146}$

The return of the ERA at a moment when originalism is more prominent is probably not a coincidence. Stare decisis may well lead even a dedicated originalist to affirm the Court's equal protection decisions on sex equality. But voters could be concerned that these decisions are at risk without an explicit textual grounding in the Constitution. In 2011, Justice Antonin Scalia explained in an interview: "Certainly the Constitution does not require discrimination on the basis of sex. The only issue is whether it prohibits it. It doesn't. Nobody ever thought that that's what it meant. Nobody ever voted for that." ${ }^{147}$ In the Illinois House, one proponent of ratifying the ERA quoted Justice Scalia's comment for the view that women were not protected by the "Constitution as written." 148 Even if the argument that a more originalist Supreme Court will lead to a rollback of the sex equality cases is nothing more than fear-mongering, this does mean that such rhetoric will be ineffective in getting the ERA ratified. ${ }^{149}$

Some originalists might also find ratification of the ERA useful because it would reduce the Court's reliance on common-law methods of constitutional interpretation. If heightened scrutiny for sex distinctions (and maybe sexual orientation or transgender discrimination) rested

debating the proposed Amendment." Id. at 692 (Powell, J., concurring). "It seems to me,” Powell added, "that this reaching out to pre-empt by judicial action a major political decision which is currently in process of resolution does not reflect appropriate respect for duly prescribed legislative processes." Id.

146 See, e.g., District of Columbia v. Heller, 554 U.S. 570 (2008) (using an originalist method to hold that the Second Amendment guarantees an individual right to own a handgun to protect the home).

147 Justice Scalia's Legally Speaking Interview from September 2011, CAL. LAW. (Feb. 2016), http://legacy.callawyer.com/2016/02/antonin-scalia-2/.

148 H.R. Transcription Debate, 100th Gen. Assemb., Reg. Sess., at 286-87 (Ill. May 30, 2018) (statement of Rep. Lang).

149 Cf. id. at 324 (statement of Rep. Welch) ("I would rather rely on the U.S. Constitution than a statute [the Civil Rights Act of 1964] that can be changed by Donald Trump. A man that hates women.”). 
on text that was more specific than the Equal Protection Clause, then those doctrines could be examples of rather than exceptions to originalism. ${ }^{150}$ Furthermore, a successful use of the Article $\mathrm{V}$ process is consistent with a broader theme of originalism that the proper method of broad constitutional change is through a constitutional amendment rather than by judicial decision. ${ }^{151}$

One challenge for that point is that no Article V amendment (save the unusual Twenty-Seventh) has been ratified in nearly fifty years. Without a successful recent example, the claim that an amendment is the only valid approach will ring hollow and be a weak spot for originalism. ${ }^{152}$

\section{Stare Decisis and Reliance}

A final consideration for Congress is whether there is something unjust about changing a ratification deadline that was widely relied upon decades ago. Though Congress has the authority to change the deadline, that does not mean that doing so is right. Even if finality is insufficient to justify denying a state a limited right to rescind its ratification of an Article $\mathrm{V}$ amendment, that does not mean that finality deserves no respect. How should this interest be taken into account?

The best premise for that analysis is that Article V, as Professor John Harrison said, "seeks to capture, in a bottle made of legal form, the lightning of American popular sovereignty." ${ }^{153}$ As a result, the procedures used to implement Article V must serve some purpose consistent with the goal of reflecting popular sovereignty. With respect to the ERA, the

150 Another way of putting this is that the ratification of the ERA might undermine the authority of other nonoriginalist cases. This prospect might raise concerns among potential supporters of the ERA, but that will depend somewhat on why they want the amendment ratified.

151 See, e.g., John O. McGinnis \& Michael B. Rappaport, Our Supermajoritarian Constitution, 80 TEX. L. REV. 703, 802-03 (2002).

152 I cannot predict what path originalism will take between now and whenever Congress might be asked to address the waiver of the ERA ratification deadline, so the thoughts outlined in the text may not end up being important to the outcome.

153 John Harrison, The Lawfulness of the Reconstruction Amendments, 68 U. CHI. L. REV. 375,375 (2001). 
best argument for not waiving the ratification deadline is that all but two of the states that ratified the ERA did so in the 1970s. Counting those states towards the three-fourths total (even when recognizing the right of one of them to rescind) could therefore be a backwards-looking take on the will of the people. For instance, some states that ratified the amendment at that time are now more conservative politically (such as West Virginia, Wyoming, North Dakota, or Montana) and might not ratify the ERA today.

One response to this point is that asking Congress to wait until thirty-eight states ratify without the five rescinding states, as Part III argued, would alleviate this concern by compelling six more states to ratify the ERA. This would mean that a significant slice of contemporary public opinion would have to support ratification actively for the Twenty-Eighth Amendment to become law. In the alternative, if Congress decided to ignore the rescissions by a greater than two-thirds vote, that would indicate (albeit in another form) that there was a wave of support for ratification in the present. In this sense, if Congress exercises restraint on the rescission question, then that can confer legitimacy on its decision to waive the ratification deadline in accord with the underlying popular sovereignty principle of Article V. Granted, the reasoning just expressed is not conclusive. Just because six states ratify between today and whenever Congress decides to take up the ratification issue does not mean that there would be a consensus for the ERA. Likewise, a decision by a particular Congress to ignore the rescissions through a supermajority vote could be the product of a single election that was highly favorable to one party and cannot be said to reflect the durable consensus that Article Five demands. Ultimately, Congress must gauge the public mood (as members regularly do) and try to assess whether wide and deep support exists for the ERA once the formalities stated in Article Five (rather than the timeline in the amendment's joint resolution) are satisfied. If that is the case, then the expiration of the 
ratification deadline need not stand in the way of the ERA's recognition as part of the

Constitution. ${ }^{154}$

In sum, Congress must take many issues into account if and when they decide whether the ERA ratification deadline should be waived. The scope of the amendment, the status of originalism, and the weight due to the reliance interest on the expired deadline will be three of the issues for lawmakers and the electorate to consider. ${ }^{155}$

\section{CONCLUSION}

Constitutional law is often more about what officials should do rather than what they can do. The possible ratification of the Equal Rights Amendment is a prime example. While this Article argued that Congress possesses the authority to waive the ERA's expired ratification deadline and disregard the state rescissions on ratification, doing both would be misguided. Changes to the nation's higher law must command a consensus to be legitimate. Generating that consensus requires respect for the formalities of Article Five and active consultation with the public. "Pulling a fast one" is not a phrase that should be associated with the ERA.

Accordingly, the watchword is patience. Congress should wait until six more states ratify the ERA before considering a deadline waiver. Failing that, Congress should follow the precedent set by the Fourteenth Amendment and hold that only a greater than two-thirds vote in the Senate and in the House of Representatives can count the five rescinding states as votes for

154 One last point worth considering is whether waiving the deadline would have adverse implications beyond the ERA. The answer is no, because no other constitutional amendment proposed by Congress but not ratified contains a ratification deadline in its joint resolution. The only impact that an ERA waiver would have for the Article $\mathrm{V}$ process is that Congress may insist in future on placing ratification deadlines into the text of the proposed amendment.

155 It is possible to imagine a general election campaign run in part of the issue of whether Congress should ratify the ERA, which would give the public another chance to render its verdict, but that scenario may not materialize. 
ratification. Only when one of these hurdles is overcome can the final issue of whether the ERA should join the Constitution be answered. 